\title{
Clomiphene versus letrozole: a better agent for ovulation induction
}

\author{
Aritra Maji, Manisha V. Ramani*, Kajal Kiran
}

Department of Obstetrics and Gynecology, MVJ Medical College and Research Hospital, Bengaluru, Karnataka, India

Received: 28 July 2020

Revised: 06 September 2020

Accepted: 08 September 2020

\section{*Correspondence:}

Dr. Manisha V. Ramani,

E-mail: manisha.ramani21@gmail.com

Copyright: ( $)$ the author(s), publisher and licensee Medip Academy. This is an open-access article distributed under the terms of the Creative Commons Attribution Non-Commercial License, which permits unrestricted non-commercial use, distribution, and reproduction in any medium, provided the original work is properly cited.

\begin{abstract}
Background: Anovulatory dysfunction is a commonly encountered problem which is responsible for about $40 \%$ of female infertility. One of the leading causes of female infertility is polycystic ovarian syndrome (PCOS). Clomiphene citrate has been the drug of choice in treating women with anovulatory infertility. However, in recent years, letrozole, an aromatase inhibitor, has emerged as alternative ovulation induction agent. Aim of this study was to compare efficacy of clomiphene citrate and letrozole as first line therapy for ovulation induction in polycystic ovarian syndrome.

Methods: This study was a hospital based prospective comparative study done in MVJ MC and RH involving 100 females suffering from infertility due to anovulation. They were divided into 2 groups of 50 each. One group was given clomiphene citrate $50 \mathrm{mg}$ while another group was given letrozole $2.5 \mathrm{mg}$ from day 3 to day 7 of menstrual cycle. Ultrasonographic follicular monitoring was done and injection beta HCG 5000 IU was given once follicle reached optimum size $(\geq 18 \mathrm{~mm})$ and endometrial thickness was adequate $(\geq 7 \mathrm{~mm})$. Patients were advised for timed intercourse after 24-36 hours of HCG administration. Ovulation was detected by sonographic findings of follicular rupture done after 48 hours. Primary outcomes measured were number of growing follicles ( $\geq 18$ mm), endometrial thickness, ovulation rate and pregnancy rate.

Results: In our study there was significant difference in the outcomes of ovulation induction between letrozole group and clomiphene group. Women who received letrozole showed improved endometrial growth $(8.44 \mathrm{~mm}$ versus 7.86 $\mathrm{mm}$ ), ovulation rate $(72 \%$ versus $56 \%)$ and pregnancy rate $(22.2 \%$ versus $14.3 \%)$ than those who received clomiphene. However, variation in follicular growth was negligible between the two groups (1.28 versus 1.36).

Conclusions: Letrozole is a superior alternative to clomiphene citrate for ovulation induction in cases of PCOS with anovulatory menstrual cycle, and can be considered as first-line therapy for ovulation induction in such women.
\end{abstract}

Keywords: Clomiphene citrate, Letrozole, Ovulation induction

\section{INTRODUCTION}

Anovulatory dysfunction is a commonly encountered problem which is responsible for about $40 \%$ of female infertility. One of the leading cause of female infertility is polycystic ovarian syndrome (PCOS). There is a significant rise in the number of PCOS cases globally. The characteristic features include obesity, increased insulin resistance and compensatory hyperinsulinemia, oligo-/anovulation, and infertility. ${ }^{1}$ The pathophysiology involves abnormal hypothalamo-pituitary-ovarian axis, ovarian theca cell hyperplasia and hyperinsulinemia. ${ }^{1}$ According to Rotterdam criteria PCOS is diagnosed by the presence of any two of the following conditions: (i) chronic anovulation, (ii) clinical/biochemical parameters for hyperandrogenism, and (iii) polycystic ovaries on ultrasonography. ${ }^{2}$ Clomiphene citrate is traditionally used as first line of ovulation-inducing agent. Its advantages include cost effectiveness, easy usage, and high ovulation rate of around $60-80 \%$. But its main drawback is low pregnancy rate. About half of it is due to its antiestrogenic property which results in depletion of estrogen 
receptors, hence inhibiting endometrial growth. ${ }^{3,4}$ Letrozole is a potent nonsteroidal aromatase inhibitor which results in ovulation induction. Letrozole diminishes estrogen production by blocking conversion of androgen to estrogen. The negative feedback to hypothalamo-pituitary axis will thereby be prevented leading to an increase in secretion of gonadotropins which will subsequently stimulate follicular development. It has a high pregnancy rate, around $80 \%$, due to its minimal antiestrogenic effect on endometrium as compared to clomiphene citrate. ${ }^{5}$ With increase in the incidence of insulin resistance and clomiphene resistance cases, letrozole can emerge as an ideal alternative for such patients.

\section{Aims and objectives}

Comparing efficacy of clomiphene citrate and letrozole as first line therapy for ovulation induction in polycystic ovarian syndrome.

\section{METHODS}

This study was a hospital based prospective comparative study conducted at MVJ Medical College and Research Hospital from $1^{\text {st }}$ May 2019 till 30 ${ }^{\text {th }}$ April 2020 after approval from the ethical and research review board of the hospital. A total of 100 females suffering from infertility due to anovulation were recruited after taking written and informed consent. They were divided into 2 groups of 50 each. One group was given clomiphene citrate $50 \mathrm{mg}$ while another group was given letrozole 2.5 mg from day 3 to day 7 of menstrual cycle. Ultrasonographic follicular monitoring was done on day 10, 12 and 14. Injection beta HCG 5000 IU was given once follicle reached optimum size $(\geq 18 \mathrm{~mm})$ and endometrial thickness was adequate $(\geq 7 \mathrm{~mm})$. Patients were advised for timed intercourse after 24-36 hours of HCG administration. Ovulation was detected by sonographic findings of follicular rupture done after 48 hours. Primary outcomes measured were number of growing follicles $(\geq 18 \mathrm{~mm})$, endometrial thickness, ovulation rate and pregnancy rate.

\section{Inclusion criteria}

Polycystic ovarian syndrome (as diagnosed by Rotterdam criteria); Patent fallopian tube; Normal endometrial cavity; Age <40 years; BMI <30; and Primary infertility.

\section{Exclusion criteria}

Endometriosis; thyroid dysfunction; hyperprolactinemia; male infertility; age $\geq 40$ years; BMI $\geq 30$; secondary infertility.

\section{Statistical analysis}

All data of various group were tabulated and statistically analysed using suitable statistical tests. $P$ value $<0.05$ was considered moderately significant and $\mathrm{p}$ value $<0.01$ as strongly significant.

\section{RESULTS}

Table 1 shows comparison between the clomiphene group and letrozole group in terms of age, BMI and duration of infertility at time of ovulation induction. The difference between the two groups was statistically insignificant.

Table 1: Comparison between the clomiphene group and letrozole group.

\begin{tabular}{|c|c|c|c|c|}
\hline Patient profile & $\begin{array}{l}\text { Group A (clomiphene } \\
\text { citrate) N=50 }\end{array}$ & $\begin{array}{l}\text { Group B } \\
\text { (letrozole) N=50 }\end{array}$ & T score & $P$ value \\
\hline Age (years) & $30.30 \pm 2.9364$ & $30.56 \pm 2.91485$ & 0.44435 & 0.328886 not significant \\
\hline BMI $\left(\mathrm{kg} / \mathrm{m}^{2}\right)$ & $23.38 \pm 2.77665$ & $23.52 \pm 3.11835$ & 0.23709 & 0.40654 not significant \\
\hline Duration of infertility (years) & $3.48 \pm 1.11098$ & $3.52 \pm 1.11098$ & 0.18002 & 0.428754 not significant \\
\hline
\end{tabular}

Table 2: Outcome of ovulation induction.

\begin{tabular}{|lllll|}
\hline $\begin{array}{l}\text { Clinical parameters after first } \\
\text { treatment }\end{array}$ & $\begin{array}{l}\text { Group A (clomiphene } \\
\text { citrate) } \mathbf{N}=\mathbf{5 0}\end{array}$ & $\begin{array}{l}\text { Group B } \\
\text { (letrozole) } \mathbf{N}=\mathbf{5 0}\end{array}$ & T score & P value \\
\hline $\begin{array}{l}\text { No. of follicles } \mathbf{1 8} \mathbf{~ m m} \text { on day } \\
\text { of HCG }\end{array}$ & $1.36 \pm 0.48487$ & $1.28 \pm 0.45356$ & 0.85201 & 0.198142 not significant \\
\hline $\begin{array}{l}\text { Endometrial thickness on day } \\
\text { of HCG }(\mathbf{m m})\end{array}$ & $7.86 \pm 0.67036$ & $8.44 \pm 0.7329$ & 4.12912 & $\begin{array}{l}0.000038 \text { strongly } \\
\text { significant }\end{array}$ \\
\hline
\end{tabular}

In Table 2, the variation in outcome of ovulation induction between the two groups was compared. The difference in number of follicles developed to optimal size $(\geq 18 \mathrm{~mm})$ in the two groups was statistically insignificant. However, the mean ET in letrozole group was $8.44 \mathrm{~mm}$ as compared to that in clomiphene group which was $7.86 \mathrm{~mm}$. The difference was strongly significant. 
Table 3: Treatment outcome.

\begin{tabular}{|llll|}
\hline $\begin{array}{l}\text { Clinical parameters } \\
\text { after first treatment }\end{array}$ & $\begin{array}{l}\text { Group A (clomiphene } \\
\text { citrate) N=50 }\end{array}$ & $\begin{array}{l}\text { Group B (letrozole) } \\
\mathbf{N}=50\end{array}$ & P value \\
\hline No. of ovulation $(\%)$ & $28(56 \%)$ & $36(72 \%)$ & $<0.00001$ strongly significant \\
\hline No. of pregnancy (\%) & $4(14.3 \%)$ & $8(22.2 \%)$ & $<0.00001$ strongly significant \\
\hline
\end{tabular}

In Table 3 comparison was done in the treatment outcome between the two groups. Both ovulation rate and pregnancy rate in letrozole group (72\% and $22.2 \%$ respectively) was significantly higher than ovulation rate and pregnancy rate (54\% and $14.3 \%$ respectively) in clomiphene group.

\section{DISCUSSION}

The past two decades have witnessed extensive research in the field of infertility, especially in assisted reproductive techniques including ovulation induction and in vitro fertilization. Various regimes are now available for ovulation induction. Clomiphene citrate has traditionally been the drug of choice for infertile females suffering from anovulatory dysfunction. Many studies support the evidence that clomiphene leads to development of good number of follicles and therefore has high ovulation rates. However, all females who ovulate with clomiphene do not conceive, thereby resulting in poor pregnancy-rates. The main reason for this has been attributed to its anti-estrogenic effects on the endometrium. ${ }^{6}$

About a decade ago, letrozole emerged as an alternative for patients suffering from clomiphene resistance or failure. Letrozole is an aromatase inhibitor that leads to monofollicular development and has no adverse effect on endometrium due to its lack of action on endometrial estrogen receptors. Moreover, letrozole has a shorter halflife of 48 hours and is cleared rapidly from body as compared to 2 weeks of clomiphene citrate often leading to accumulation over subsequent cycles. ${ }^{7}$ In our study, we aim to evaluate and compare efficacy of both drugs individually in patients of polycystic ovarian syndrome.

\section{Patient profile}

The patient profile was comparable in both groups with no significant difference between age (30.30 versus 30.56 years), BMI (23.38 versus $\left.23.52 \mathrm{~kg} / \mathrm{m}^{2}\right)$ and duration of infertility (3.48 versus 3.52 years).

\section{Follicular development}

In our study, we found no significant difference in the number of follicles developed $(>18 \mathrm{~mm})$ at the time of HCG administration between the two groups $(1.36 \pm 0.48$ versus $1.28 \pm 0.45, \mathrm{p}$ value $=0.198)$. This was similar to the results of Ghomian et at in 2015 who also demonstrated no significant difference in follicular development between clomiphene and letrozole. ${ }^{8}$ Many previous studies, however, have observed significant increase in follicular development in patients treated with clomiphene citrate as compared to letrozole. ${ }^{9-11}$ Contrary to these studies, Hedge et al in 2020 reported significantly higher follicular development in letrozole group. $^{12}$

\section{Endometrial thickness}

This outcome has by far been stated as the biggest drawback of clomiphene citrate and thus been considered the very reason for its lower pregnancy rate. We found a significantly higher endometrial thickness in letrozole group $(8.44 \pm 0.73 \mathrm{~mm})$ as compared to clomiphene citrate $(7.86 \pm 0.67)$ with a $p$ value of 0.000038 . Our observations are supported by majority of the previously done studies. ${ }^{9-12}$ To overcome endometrial thinning by clomiphene citrate, Harira in 2018 added estradiol valerate $(4 \mathrm{mg})$ to the patients receiving clomiphene from day 8-14. Despite the addition of estrogen to the regimen, the study reported higher endometrial thickness in letrozole group $(9.2 \pm 1.8)$ as compared to $\mathrm{CC}+\mathrm{E}_{2}$ group $(8.28 \pm 1.7)$. The difference was significant with $\mathrm{p}$ value $<0.00 .^{13}$

However, contrary results were published by Bedawy et al in 2009. They conducted a large RCT trial involving 438 woman and reported endometrial thickness more in CC group as compared to letrozole group (9.2 \pm 0.7 vs $8.1 \pm 0.2, \mathrm{p}$ value $=0.02)$. ${ }^{14}$ In 2015 , Ghomian et al observed no significant difference in endometrial thickness in both groups. ${ }^{8}$

\section{Ovulation rate and pregnancy rate}

In our study we observed significantly higher ovulation rate as well as pregnancy rate in letrozole group. Twenty eight out of $50(56 \%)$ patients in group A i.e. the clomiphene citrate group ovulated, however only 4 of them became pregnant (14.3\%). On the other hand, group B i.e. the letrozole group observed almost $72 \%$ ovulation rate (36 out of 50) with almost $22.2 \%$ conception rate (8 out of 36). The difference in ovulation rate as well as pregnancy rate was highly significant with $p$ value of $<0.00001$ in both outcomes.

In congruence to our study, Atay et al and Legro et al found higher ovulation as well as pregnancy rates in letrozole group. ${ }^{9,15}$ Similar results were demonstrated in 2020 by Hedge. ${ }^{12}$ A previous study done by Roy et al in 
2012 found slightly higher ovulation rates $(67.9 \%$ versus $66.6 \%)$ in $\mathrm{CC}$ group however these were not significant. In spite of comparable ovulation rates, they reported significantly higher pregnancy rates in letrozole group. ${ }^{10}$

On the contrary, Bedawy et al 2009 found similar ovulation and pregnancy rates. They therefore concluded no benefit of letrozole over clomiphene as the former is a costlier drug than latter. ${ }^{14}$ These results were supported later by studies by Nahid et al and Sharief et al in 2015 who reported that despite significantly higher ovulation rate in letrozole group the pregnancy rate between the two groups was not significant. ${ }^{11,16}$ Al-Shaikh et al conducted a study on 85 PCOS women with subfertility. The study concluded that letrozole was the better in comparison to clomiphene in regard to responded cycles and mean number of mature follicles whereas regarding to endometrial thickness, mono-follicular cycles, and pregnancy rate (per cycle), clomiphene was the better. ${ }^{17}$

Infertility and its treatment can be physically and mentally exhausting for the couple. It requires immense patience and compliance. The usual practice is to start from a simple regime using single drug and gradually moving on to a more complex treatment depending upon the response. ${ }^{18}$ In the past, the conventional course of treatment for anovulatory females included starting with low dose of clomiphene citrate and gradually increasing the dosage from $50 \mathrm{mg}$ to $150 \mathrm{mg}$. Clomiphene resistance was observed in around $25 \%$ females. Although ovulation was observed in $75 \%$ of cases, only $30-40 \%$ cases became pregnant. ${ }^{6}$ Therefore almost two-third of females were expected to fall in category of either clomiphene resistance or failure. Ovulation induction in these females was then done with letrozole. This step-up approach would usually take months to reach to diagnosis of clomiphene failure. Therefore, Casper et al suggested use of letrozole as first line treatment in older females, thus bypassing several months of wait. Especially in older females. ${ }^{19}$ This was further supported by the work of Amer S et al, which reported higher efficacy of letrozole in respect to pregnancy rates with shorter time-topregnancy. ${ }^{20}$

Therefore, does the extensive research done on ovulation induction settle the ongoing debate- Can letrozole be used as the first line drug in anovulatory females? The results are conflicting. Our study suggests letrozole to be superior to clomiphene citrate however, due to our small sample size, the same results could not be generalized. There is a need for more well-controlled randomized trials with large sample size to lay rest to this question.

\section{CONCLUSION}

Letrozole is a superior alternative to clomiphene citrate for ovulation induction in cases of polycystic ovarian syndrome with anovulatory menstrual cycle, and can be considered as first-line therapy for ovulation induction in such women.
Funding: No funding sources

Conflict of interest: None declared

Ethical approval: The study was approved by the Institutional Ethics Committee

\section{REFERENCES}

1. The Rotterdam ESHRE/ASRM-Sponsored PCOS Consensus Workshop Group. Revised 2003 consensus on diagnostic criteria and long-term health risks related to polycystic ovary syndrome. Fertil Steril. 2004;81:19-25.

2. Saxena P, Prakash A, Nigam A, Mishra A. Polycystic ovary syndrome: Is obesity a sine qua non? A clinical, hormonal, and metabolic assessment in relation to body mass index. Indian $\mathrm{J}$ Endocrinol Metab. 2012;16:996-9.

3. Gorlitsky GA, Kase NG, Speroff L. Ovulation and pregnancy rates with clomiphene citrate. Obstet Gynecol. 1978;51:265-9.

4. Dickey RP, Taylor SN, Curole DN, Rey PH, Pyrzak $\mathrm{R}$. Incidence of spontaneous abortion in clomiphene pregnancies. Hum Reprod. 1996;11:2623-8.

5. Mitwally MF, Casper RF. Use of an aromatase inhibitor for induction of ovulation in patients with an inadequate response to clomiphene citrate. Fertil Steril. 2001;75:305-9.

6. Homburg R. Clomiphene citrate- end of an era? A mini review. Hum Reprod. 2005;20:2043-51.

7. Young SL, Opashi MS, Fritz MA. Serum concentration of euclomiphene and zuclomiphene across consecutive cycles of clomiphene citrate therapy in anovulatory infertile women. Fertil Steril. 1999;71:639-44.

8. Ghomian N, Khosravi A, Mousavifar N. A randomized clinical trial on comparing the cycle characteristics of two different initiation days of letrozole treatment in clomiphene citrate resistant PCOS patients in IUI cycles. Int J Fertil Steril. 2015;9(1):17-26.

9. Atay V, Cam C, Muhcu M, Cam M, Karateke A. Comparision of letrozole and clomiphene citrate in women with polycystic ovaries undergoing ovarian stimulation. J Int Med Res. 2006;34:73-6.

10. Roy KK, Baruah J, Singla S, Sharma JB, Singh N, Jain SK, et al. A prospective randomized trial comparing the efficacy of letrozole and clomiphene citrate in induction of ovulation in polycystic ovarian syndrome. J Human Reprod Sci. 2012;5(1):20-5.

11. Sharief M, Nafee NR. Comparison of letrozole and clomiphene citrate in women with polycystic ovaries undergoing ovarian stimulation. J Pak Med Assoc. 2015;65(11):1149-52.

12. Hegde R, Maitra C. Comparison of the role of letrozole and clomiphene citrate as a first line ovulation induction drug in infertile women with polycystic ovary syndrome. Indian J Obstet Gynecol Res. 2020;7(1):12-5.

13. Harira M. Use of Letrozole versus clomipheneestradiol for treating infertile women with 
unexplained infertility not responding well to clomiphene alone, comparative study. Middle East Fertil Soc J. 2018;23:384-7.

14. Badawy A, Abdel Aal I, Abulatta M. Clomiphene citrate or Letrozole in women polycystic ovarian syndrome: a prospective randomized trial. Fertil Steril. 2009;92:849-52.

15. Legro RS, Brzyski RG, Diamond MP, Coutifaris C, Schlaff WD, Casson P, et al. Letrozole versus clomiphene for infertility in the polycystic ovary syndrome. N Engl J Med. 2014;371:119-29

16. Nahid L, Sirous K. Comparison of the effects of letrozole and clomiphene citrate for ovulation induction in infertile women with polycystic ovary syndrome. Minerva Ginecol. 2012;64(3):253-8.

17. Al-Shaikh S, Al-Mukhatar E, Al-Zubaidy A, AlRubaie B, Al-Khuzaee L. Use of clomiphene or letrozole for treating women with polycystic ovary syndrome related subfertility in Hilla city. Middle East Fertil Soc J. 2017;22(2):105-10.

18. Kamath MS, George K. Letrozole or clomiphene citrate as first line for anovulatory infertility: a debate. Reprod Biol Endocrinol. 2011;9:86.

19. Casper RF. Letrozole versus clomiphene citrare: which is better for ovulation induction? Fertil Steril. 2009;92:858-9.

20. Amer SA, Smith J, Mahran A, Fox P, Fakis A. Double-blind randomized controlled trial of letrozole versus clomiphene citrate in subfertile women with polycystic ovarian syndrome. Hum Reprod. 2017;32(8):1631-8.

Cite this article as: Maji A, Ramani MV, Kiran K. Clomiphene versus letrozole: a better agent for ovulation induction. Int J Reprod Contracept Obstet Gynecol 2020;9:4145-9. 